\title{
On Radiative Corrections due to Soft Photons.
}

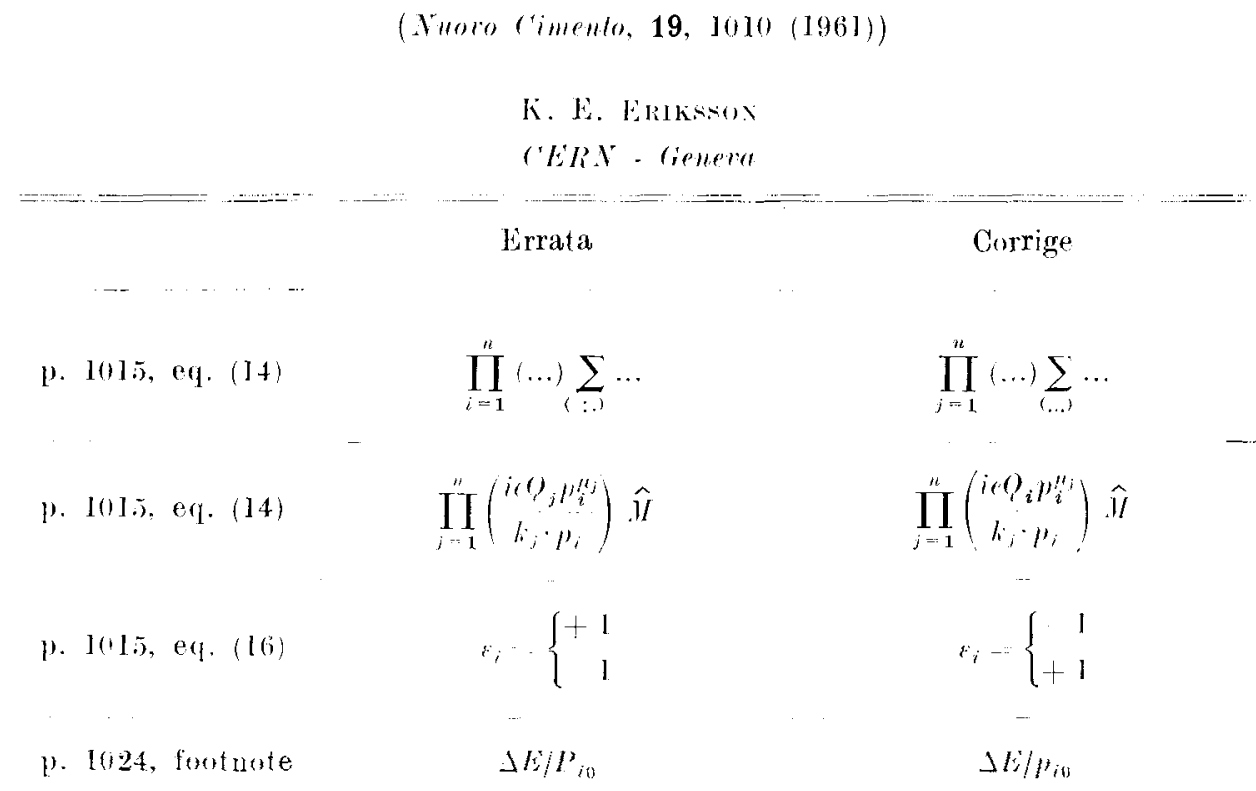

\section{Radiative Corrections to Muon-Electron Scattering.}

(Nuoro rimenlo, 19, 1029 (1961))

K. E. ERJising

CERN - Genere

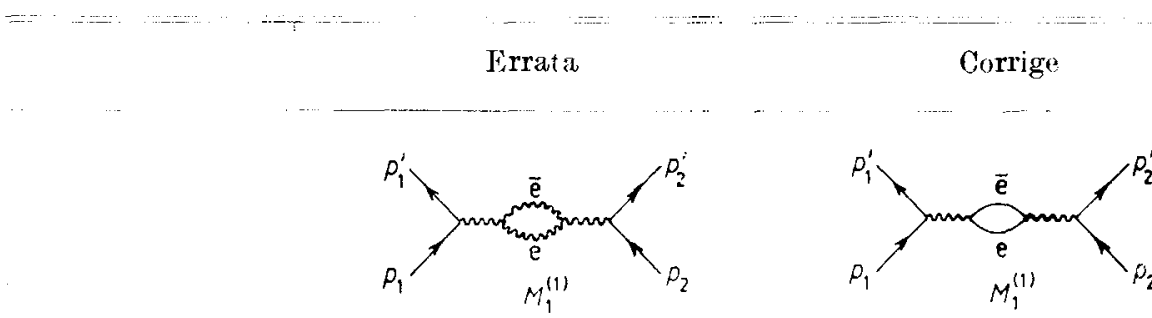

p. 1032, Fig. 3
